\title{
Outcomes on mesh fixation vs non-fixation in laparoscopic totally extra peritoneal inguinal hernia repair: a comparative study
}

Abu Kamal Nahid(D), Sanjida Rahman(D), Keerthanaa Veerapatherar(D), Roland Fernandes(D)

Clinic of General and Colorectal Surgery, William Harvey Hospital, Ashford, United Kingdom

\section{ABSTRACT}

Objective: Inguinal hernia repair is one of the most common general surgical procedure, and laparoscopic approach gained popularity over the open approach. This study aimed to compare the clinical effects of TEP inguinal hernioplasty with or without mesh fixation. The primary outcome was acute post-operative pain.

Material and Methods: A retrospective comparative study on a prospectively collected data was conducted in a large DGH in England between January 2017 and December 2019 on 47 patients. The patients were divided into two groups. In group A, mesh fixation was performed with absorbable tackers and in group B no fixation was performed. Patients were followed up to 18 months postoperatively. Data was collected on post-operative pain, cost, recurrences and time taken to return to normal activities. Patients with lower midline scar and complicated inguinal hernias were excluded.

Results: Out of the 47 patients $53 \%(n=25)$ were in group $A$ and $47 \%(n=22)$ in group B. All the patients in both groups were male. The mean postoperative pain score at 72h in group A was 7.12 (SD 1.13) and 4.91 (SD 1.23) in group B ( $<<0.001)$. Group B patients have taken shorter time to return to normal activities in comparison to group $A(p<0.001)$, while recurrence $(2 \%)$ rate is higher in group $B(p>0.05)$.

Conclusion: Pain and time taken to return to normal work postoperatively were significantly less in the non-fixation group. The study recommends non-fixation over fixation as it is feasible, cost-effective, causes less post-operative pain and no differences in terms of recurrences.

Keywords: Inguinal hernia, laparoscopic, mesh, fixation, non-fixation, chronic pain

Cite this article as: Nahid AK, Rahman S, Veerapatherar K Fernandes R. Outcomes on mesh fixation vs non-fixation in laparoscopic totally extra peritoneal inguinal hernia repair: a comparative study. Turk J Surg 2021; 37 (1): 1-5.

Corresponding Author

Abu Kamal Nahid

E-mail:m.nahid@nhs.net

Received: 06.10.2020

Accepted: 12.01.2021

Available Online Date: 22.03.2021

@ Copyright 2021 by Turkish Surgical Society Available online at www.turkjsurg.com

DOI: $10.47717 /$ turkjsurg.2021.4962

\section{INTRODUCTION}

Inguinal hernias are a significant cause of patient morbidity. It is the most common type of hernia, accounting for $75 \%$ of all the abdominal wall hernias. The prevalence of repair ranges from 10 per 100000 of the population in the United Kingdom to 28 per 100000 in the United States (1). It has been estimated that over 20 million inguinal hernia operations are carried out each year throughout the world. The lifetime risk is approximately $27 \%$ in males and $3 \%$ in females (1). Several methods of inguinal hernia repair have been described and have been evolved over time $(2,3)$. Historically, the first operations for inguinal hernias were performed by the end of the $16^{\text {th }}$ century. In the early 1980s, minimally invasive techniques for inguinal hernia repair were first reported, adding another modality to the management of these hernias (4). Laparoscopic approach of inguinal hernia repair has gained popularity over open approach due to reducing postoperative pain, shorter hospital stay, decreased incidence of urinary retention and earlier return to normal activities (5). National Institute for Health and Care Excellence (NICE) guidelines also advocates the superiority of the laparoscopic approach over open inguinal hernia repair (6). Two laparoscopic techniques have become the mainstay for the repair of these hernias: Trans Abdominal Pre-Peritoneal repair (TAPP) and Totally Extraperitoneal (TEP) repair. Both approaches have been proven to be effective, however, several fundamental differences exist when comparing the two approaches (7-9).

Mesh placement is the most frequently debated issue of TEP or TAPP operation. Mesh can be placed without fixation or can be fixed into place with tackers. However, these metal tackers increase the cost, operative times and there is an increased incidence of 
chronic groin pain (2-16\%) (5,10-14). One of the main concerns for non-fixation is mesh displacement or migration and subsequently increasing the chances of recurrence. However, several recent studies have shown that non-fixation of the mesh does not lead to an increase in recurrences. Moreover, it has the advantages of shorter operative time and less chronic groin pain when compared to tacker fixation (5,10-14).

The aim of this study was to compare the clinical effects of laparoscopic TEP inguinal hernioplasty with or without mesh fixation. Primary outcome was acute post-operative pain. Secondary outcome measures included time taken to return to normal activities, cost, complications and recurrence rates.

\section{MATERIAL and METHODS}

A retrospective study on a prospectively collected data was conducted in a large District General Hospital in South-East England between January 2017 and December 2019 on 47 patients with inguinal hernias presenting electively for TEP inguinal hernia repair with accepted written consents. Group A (25 patients) underwent TEP with mesh fixation by absorbable tackers versus Group B (22 patients) who received TEP with mesh non-fixation. Data was collected on post-operative acute and chronic groin pain, recurrences, time taken to return to normal daily activities, cost and any other complications. Timely post-discharge follow-ups were conducted up to 18 months through telephone on the third post-operative day and regular outpatient clinics appointment in 6 months and 12 months interval.

All adult patients with uncomplicated inguinal hernias were included. Exclusion criteria included lower midline scars and complicated (obstructed or strangulated) inguinal hernias. All patients received a single intravenous dose of $1.2 \mathrm{gm}$. Co-amoxiclav before induction as prophylaxis. The procedure was done under general anesthesia. We did employ urinary bladder catheterization pre-operatively. All procedures performed in this study were in accordance with the ethical standards of trust, and the study was discussed by the local research committee. However, ethical approval was not required as there is no deviation from the current practice and both techniques are widely practiced in the UK. Informed consent was obtained from all individual participants. The study complies with the current laws of the UK.

\section{Surgical Technique}

Access to the preperitoneal space was obtained by a 10-mm infraumbilical port placement anterior to the posterior rectus sheath. Once the access was confirmed, dissection of the preperitoneal space was initiated with a balloon dissector to place a 10-mm $30^{\circ}$ telescope. The pneumo pressure was $12 \mathrm{mmHg}$. Two $5-\mathrm{mm}$ ports were placed in the midline, one three finger breadths above the symphysis pubis and the other in between the 10-mm port and 5-mm supra-pubic port, and the entire posterior floor was dissected. Once enough space was created to visualize the pu- bic symphysis medially, the cord structures entering the deep ring laterally, and adequate lateralization till Anterior Superior Iliac Spine, the hernia was addressed. For indirect hernias, cord dissection was done to isolate the sac completely. Direct hernia defects were identified and contents in the hernia defect were reduced. Once hernia was completely reduced, rolled $12 \times 15 \mathrm{~cm}$ polypropylene mesh was introduced via the $10-\mathrm{mm}$ port. The mesh was spread to cover the entire myopectineal area to cover the defect. The lower edge must extend well below the level of the inguinal ligament. The lateral part of the patch folded over and extended beyond the iliac vessels. In bilateral hernias, a similar mesh was placed bilaterally. The mesh was fixed with absorbable tackers, medially on Cooper's ligament and laterally near anterior superior iliac spine. This step was not performed during the mesh non-fixation period. The procedure was completed after complete desufflation under vision until creeping of the peritoneum and its filling over the mesh, ensuring that the inferior border of the mesh will not roll up and closing the port sites with appropriate sutures. Early ambulation was encouraged. The patients were advised to undergo regular daily activities except for lifting heavy weights or involving in strenuous activity/exercise for at least 6-8 weeks.

\section{Statistical Analysis}

Statistical analysis was performed using SPSS software version 25. Data was expressed as mean \pm standard deviation (SD). Comparisons of quantitative data in both groups were analyzed using t-test. Values of $p<0.05$ were considered statistically significant.

\section{RESULTS}

Total eligible patients for the study was 54 , however, later 7 patients were excluded. Of the 47 patients, $53 \%(n=25)$ were in Group A and 47\% ( $n=22)$ in Group B. All the patients in both groups were male with an overall mean age of 56 years (range: $22-$ 83 years). In group A (fixation group), unilateral hernias were $28 \%$ $(n=7)$ and bilateral hernias were $72 \%(n=18)$, whereas in Group B (non-fixation group), unilateral hernias were 18\% $(n=4)$ and bilateral hernias were $82 \%(n=18),(p>0.05)$ (Table 1).

Visual analogue pain scale (VAPS) given to patients were used post-operatively at 72 hours for pain assessment via telephone. Mean postoperative pain score in Group A was $7.12 \pm 1.13$ and $4.91 \pm 1.23$ in Group B, $(p<0.001)$ (Figure 1).

Mean time taken to return to normal activities for group $B$ was $4.68 \pm 1.62$ in comparison to Group A 6.24 \pm 1.33 , ( $p<0.001$ ) (Table 2). The extra cost of the operation for each patient in Group A was approximately GBP 300 for NHS England, which is the added cost for absorbable tackers.

There was one recurrence (2\%) encountered in the 18th month follow-up in Group B ( $p>0.05$ ), which was statistically insignificant. No cases needed conversion to open hernia repair, and there were no bowel and visceral injuries in our study. No patients developed seroma, hematoma, urinary retention or infection. No cases with 
Table 1. Patient demographics and characteristics of hernia

\begin{tabular}{|l|c|c|}
\hline Variables & Fixations (n=25) & Non-fixation $(\mathbf{n}=\mathbf{2 2})$ \\
\hline Age (years) & & 55 \\
\hline Mean & 58 & 22 \\
\hline Sex & & 0 \\
Male & 25 & $4(18 \%)$ \\
Female & 0 & $18(82 \%)$ \\
Unilateral Hernias (\%) & $7(28 \%)$ & \\
Bilateral Hernias (\%) & $18(72 \%)$ & \\
\hline
\end{tabular}

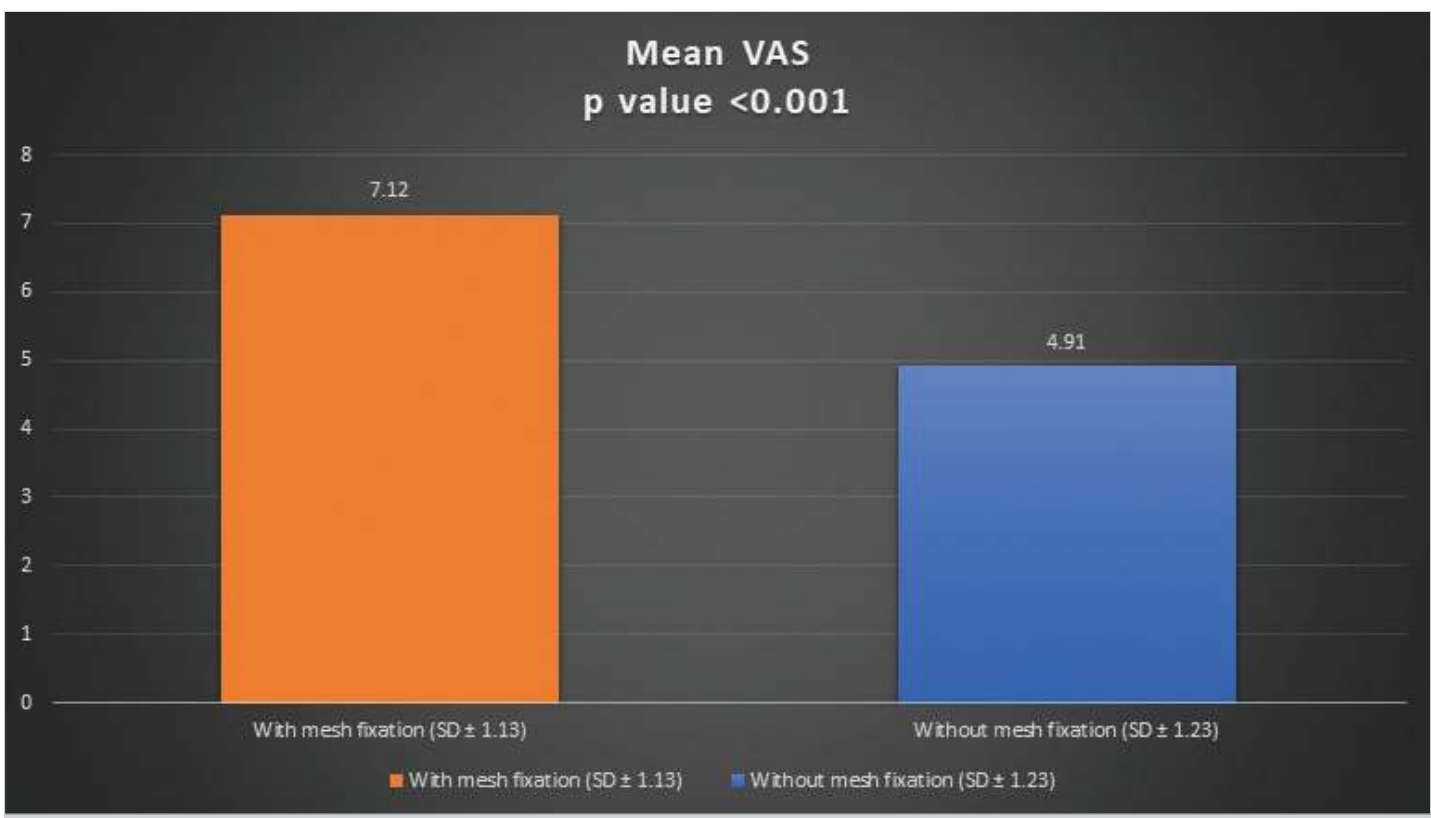

Figure 1. Comparison of post-operative pain in two groups at 72 hours.

\begin{tabular}{|l|c|c|c|}
\hline Table 2. Comparison between the two groups according to time taken to return to normal activities & Group B (n= 22) [n (\%)] & p \\
\hline Return to normal activities & Group A (n= 25) [n (\%)] & $6(27 \%)$ & $<0.001$ \\
\hline 2-3 days & $1(4 \%)$ & $10(46 \%)$ & $<0.001$ \\
\hline $4-5$ days & $4(16 \%)$ & $6(27 \%)$ & $<0.001$ \\
\hline 6-7 days+ & $20(80 \%)$ & $4.68 \pm 1.62$ & \\
\hline Mean \pm SD & $6.24 \pm 1.33$ & 5 & \\
\hline Median & 7 & 5 & \\
\hline
\end{tabular}

chronic groin pain in this study were encountered in both groups with 15-18-month follow-up.

\section{DISCUSSION}

Laparoscopic hernia repair is now recommended for primary inguinal hernia, recurrent inguinal hernia repair and bilateral inguinal hernia $(2,3,6)$. Laparoscopic Totally Extraperitoneal (TEP) repair has gained popularity over Trans Abdominal Pre-Peritoneal repair (TAPP) repair as it does not involve breach into the peritoneal cavity and subsequent risks of visceral injuries (7-9). Inguinal hernias are being considered effectively treated by the TEP laparoscopic approach allowing bilateral repairs in the same sitting by minimally invasive technique. Understanding the posterior inguinal canal anatomy is essential to perform a laparoscopic TEP (17).

In this study, our aim was to ascertain patients' functional outcomes after a laparoscopic TEP between mesh fixation and non-fixation. Many studies advocate the superiority of the mesh non-fixation over the fixation (15-17,19-21). However, it has remained debatable and controversial. The main concerns for non-fixation are mesh migration and the recurrence rate. In TEP, stabilization of the nonfixated mesh placed between anterior wall 
of the abdomen and peritoneum is based on sandwich effect created between tissues. Mesh stabilization without fixation has been well described in the literature (19-21). Meta-analyses have also comprehensively concluded that the recurrence rates are not increased by non-fixation of the mesh (15-18,20). Moreover, the non-fixation procedure can avoid the risk of vessel and nerve injury associated with tacker fixation. Postoperatively within two weeks, the proliferation of mesenchymal cells occurs in the mesh, and in the next two months, the tissue starts to incorporate into the mesh and adequate amount of collagen develops. This eventually strengthens permanent stabilization of mesh in the preperitoneal area.

Several methods of mesh fixation have been described and practiced such as surgical adhesives (Fibrin glue), self-fixating mesh and mechanical fixation (Tackers or sutures). The main reason for fixation is to avoid migration and theoretical recurrences. However, the use of fibrin sealant may lead to fibrin glue reactions, but many studies have proven its efficacy as safe $(15,22,23)$. Suture fixation is barely practised as it is time-consuming and has not shown any benefits over non-fixation or tacker fixation. Tackers are the most common method of mesh fixation. They can be both absorbable and non-absorbable. The main concerns are post-operative acute and chronic pain due to greater risks of nerve injury $(5,10,14,19,22)$. The use of fixation devices in the conjoint tendon or the pubic tubercle can be a causative factor for postoperative pain and discourage early ambulation. Approximately 2-16\% of patients may experience persistent pain after laparoscopic inguinal hernia repairs. This may again promote seroma formation and increase hospital stay. Our study also found increased pain scores in the fixation group when we assessed pain at $72 \mathrm{~h}$ post-surgery and this was statistically significant (Figure 1).

In our study, we also looked at the time taken by the patients to return to their normal activities postoperatively. Non-fixation group took a statistically significant shorter time in comparison to the fixation group in return to their daily activities. Cost is the other issue that needs to be considered while using tackers, and our study indeed showed tackers cost additional money compared to non-fixation. Several meta-analyses and RCTs have shown that non-fixation of mesh leads to decreased cost $(16,17,20)$.

A very important finding in this study was that the non-fixation of mesh did not lead to increased recurrence. This is in agreement to the results of randomized trials and meta-analysis looking at non-fixation of mesh (7,15-17,19-21). Moreover, the superiority of nonfixation method in terms of avoiding potential nerve damage as well as limiting surgical expenses has been acknowledged.

\section{CONCLUSION}

Laparoscopic TEP repair for inguinal hernia is recommended for both direct and indirect inguinal hernias as providing a safe operative technique with early recovery and return to normal activities. Our results support the findings of researchers and demonstrate that laparoscopic TEP inguinal hernia repair performed without mesh fixation is a reliable technique. We recommend non-fixation over fixation as it is feasible, cost-effective, causes less post-operative pain and no differences in terms of recurrences. Our study is limited by its limited number of patients and relatively short follow up period. Also, patients were not randomized using RCT, which introduced potential selection bias. However, selection bias is a confounding factor.

Ethics Committee Approval: All procedures performed in this study were in accordance with the ethical standards of trust, and the study was discussed by the East Kent Hospitals University NHS Foundation Trust, UK.

Peer-review: Externally peer-reviewed.

Author Contributions: Concept - R.F., A.K.N.; Design - A.K.N.; Supervision - R.F., A.K.N.; Materials - A.K.N., R.F.; Data Collection and/or Processing - All of authors; Literature Review - A.K.N.; Writing Manuscript - A.K.N.; Critical Reviews - R.F.

Conflict of Interest: The authors declare that they have no conflict of interest.

Financial Disclosure: The authors declared that this study has received no financial support.

\section{REFERENCES}

1. Jenkins JT, O'D wyer PJ. Inguinal hernias. BMJ 2008; 336(7638): 269-72. [CrossRef]

2. Simons MP, Smietanski M, Bonjer HJ, Bittner R, Miserez M, Aufenacker $T$, et al. International guidelines for groin hernia management. Hernia 2018; 22(1): 1-165. [CrossRef]

3. Miserez M, Peeters E, Aufenacker T, Bouillot JL, Campanelli G, Conze J, et al. Update with level 1 studies of the European Hernia Society guidelines on the treatment of inguinal hernia in adult patients. Hernia 2014; 18(2): 151-63. [CrossRef]

4. Lau WY. History of treatment of groin hernia. World J Surg 2002; 26(6): 748-59. [CrossRef]

5. Zhu X, Cao H, Ma Y, Yuan A, Wu X, Miao Y, et al. Totally extraperitoneal laparoscopic hernioplasty versus open extraperitoneal approach for inguinal hernia repair: a meta-analysis of outcomes of our current knowledge. Surgeon 2014; 12(2): 94-105. [CrossRef]

6. NICE. Laparoscopic surgery for inguinal hernia repair. 2004. p. https:// www.nice.org.uk/guidance/ta83. [CrossRef]

7. Köckerling F, Schug-Pass C, Jacob DA, Keller T. The Intra- and postoperative complication rate of tep in patients undergoing unilateral endoscopic inguinal hernia repair is not higher compared with TAPP. World J Surg 2013; 37(4): 933-4. [CrossRef]

8. Bracale U, Melillo P, Pignata G, Di Salvo E, Rovani M, Merola G, et al. Which is the best laparoscopic approach for inguinal hernia repair: TEP or TAPP? A systematic review of the literature with a network meta-analysis. Surg Endosc 2012; 26(12): 3355-66. [CrossRef]

9. Varcus F, Duta C, Dobrescu A, Lazar F, Papurica M, Tarta C. Laparoscopic repair of inguinal hernia TEP versus TAPP. Chirurgia (Bucur) 2016; 111(4): 308-12. [CrossRef]

10. Linderoth G, Kehlet H, Aasvang EK, Werner MU. Neurophysiological characterization of persistent pain after laparoscopic inguinal hernia repair. Hernia 2011; 15(5): 521-9. [CrossRef] 
11. van der Pool AEM, Harlaar JJ, den Hoed PT, Weidema WF, van Veen RN. Long-term follow-up evaluation of chronic pain after endoscopic total extraperitoneal repair of primary and recurrent inguinal hernia. Surg Endosc 2010; 24(7): 1707-11. [CrossRef]

12. Öberg S, Andresen K, Klausen T, Rosenberg J. Chronic pain after mesh versus nonmesh repair of inguinal hernias: A systematic review and a network meta-analysis of randomized controlled trials. Surgery 2018; 163. [CrossRef]

13. Eklund A, Montgomery A, Bergkvist L, Rudberg C. Chronic pain 5 years after randomized comparison of laparoscopic and Lichtenstein inguinal hernia repair. Br J Surg 2010; 97(4): 600-8. [CrossRef]

14. Gutlic N, Rogmark P, Nordin P, Petersson U, Montgomery A. Impact of Mesh Fixation on Chronic Pain in Total Extraperitoneal Inguinal Hernia Repair (TEP): A Natio [CrossRef] nwide Register-based Study. Ann Surg 2016; 263(6): 1199-206.

15. Kaul A, Hutfless S, Le H, Hamed SA, Tymitz K, Nguyen H, et al. Staple versus fibrin glue fixation in laparoscopic total extraperitoneal repair of inguinal hernia: a systematic review and meta-analysis. Surg Endosc 2012; 26(5): 1269-78. [CrossRef]

16. Tam K-W, Liang H-H, Chai C-Y. Outcomes of staple fixation of mesh versus nonfixation in laparoscopic total extraperitoneal inguinal repair: a meta-analysis of randomized controlled trials. World J Surg 2010; 34(12): 3065-74. [CrossRef]

17. Ferzli GS, Frezza EE, Pecoraro AMJ, Ahern KD. Prospective randomized study of stapled versus unstapled mesh in a laparoscopic preperitoneal inguinal hernia repair. J Am Coll Surg 1999; 188(5): 461-5. [CrossRef]
18. Sajid MS, Ladwa N, Kalra L, McFall M, Baig MK, Sains P. A meta-analysis examining the use of tacker mesh fixation versus glue mesh fixation in laparoscopic inguinal hernia repair. Am J Surg 2013; 206(1): 103-11. [CrossRef]

19. Sajid MS, Ladwa N, Kalra L, Hutson K, Sains P, Baig MK. A meta-analysis examining the use of tacker fixation versus no-fixation of mesh in laparoscopic inguinal hernia repair. Int J Surg 2012; 10(5): 224-31. [CrossRef]

20. Teng YJ, Pan SM, Liu YL, Yang KH, Zhang YC, Tian JH, et al. A metaanalysis of randomized controlled trials of fixation versus nonfixation of mesh in laparoscopic total extraperitoneal inguinal hernia repair. Surg Endosc 2011; 25(9): 2849-58. [CrossRef]

21. Garg P, Nair S, Shereef M, Thakur JD, Nain N, Menon GR, et al. Mesh fixation compared to nonfixation in total extraperitoneal inguinal hernia repair: a randomized controlled trial in a rural center in India. Surg Endosc 2011; 25(10): 3300-6. [CrossRef]

22. Shah NS, Bandara Al, Sheen AJ. Clinical outcome and quality of life in 100 consecutive laparoscopic totally extra-peritoneal (TEP) groin hernia repairs using fibrin glue (Tisseel): a United Kingdom experience. Hernia 2012; 16(6): 647-53. [CrossRef]

23. Berney $C R$, Descallar J. Review of 1000 fibrin glue mesh fixation during endoscopic totally extraperitoneal (TEP) inguinal hernia repair. Surg Endosc 2016; 30(10): 4544-52. [CrossRef]

\section{ORIJINAL ÇALIŞMA-ÖZET}

Turk J Surg 2021; 37 (1): 1-5

\section{Laparoskopik total ekstra-peritoneal inguinal herni tedavisinde sabitlemeli ve sabitlemesiz meş uygulamalarının sonuçları}

Abu Kamal Nahid, Sanjida Rahman, Keerthanaa Veerapatherar, Roland Fernandes

William Harvey Hastanesi, Genel ve Kolorektal Cerrahi Kliniği, Ashford, Birleşik Krallık

\section{ÖZET}

Giriş ve Amaç: Inguinal herni onarımı en yaygın cerrahi işlemlerden biri olmakla birlikte laparoskopik yaklaşım açık yaklaşıma göre daha büyük popülariteye sahiptir. Bu çalışma, sabitlemeli ve sabitlemesiz meş yerleştirilen TEP inguinal hernioplastinin klinik sonuçlarını araştırmaktı. Primer sonuç ise akut postopertif ağrı idi.

Gereç ve Yöntem: Prospektif olarak toplanan verilerden retrospektif karşılaştırmalı bir çalışma Ocak 2017 ve Aralık 2019 tarihleri arasında İngiltere'de 47 hastada uygulandı. Hastalar iki gruba ayrıldı. Grup A'da absorbe olabilen zımbalarla meş sabitlemesi uygulanırken Grup B'de bu tür bir sabitleme uygulanmadı. Hastalar postoperatif 18. aya kadar takip edildi. Postoperatif ağrı, maliyet, nüks ve normal faaliyetlere dönüş açısından veriler kaydedildi. Alt orta hat skarı ve komplike inguinal hernisi olan hastalar çalışma dışında tutuldu.

Bulgular: Kırk yedi hastanın \%53'ü ( $n=25)$ Grup A'da \%47'si ise ( $n=22)$ Grup B'de idi. Her iki gruptaki tüm hastalar erkekti. Grup A'da 72 . saatte postoperatif ağıı skoru 7.12 (SD 1.13), Grup B'de 4.91 (SD 1.23) idi ( $p<0,001$ ). Grup A hastalarına nazaran, Grup B hastaları daha erken sürede normal faaliyetlerine döndü $(p<0.001)$ ancak Grup B'de nüks oranı $(\% 2)$ daha yüksekti $(p>0,05)$.

Sonuç: Postoperatif ağrı ve normal faaliyetlere dönüş sabitleme yapılmayan grupta anlamlı derecede daha düşüktü. Çalışmamızın sonuçları, uygulanabilir ve uygun maliyetli olduğundan ve daha az postoperatif ağrıya sebep olmasından ve nüks açısından herhangi bir fark göstermemesinden ötürü sabitlemesiz meş yerleştirme işlemini önermektedir.

Anahtar Kelimeler: Inguinal herni, laparoscopik, meş, sabitleme, kronik ağrı

DOi: $10.47717 /$ turkjsurg.2021.4962 